\title{
Invitro Efficacy of Fungicides against Fusarium oxysporum f. sp. lycopersici causing Fusarium Wilt of Tomato
}

\author{
M. M. Bhujbal*, C. D. Deokar, D. A. Bachkar, J. S. Suryawanshi and N. M. Daingade \\ Department of Plant pathology, College of Agriculture, Dhule (MS), Mahatma Phule Krishi \\ Vidyapeeth, Rahuri, India \\ *Corresponding author
}

\section{A B S T R A C T}

\section{Keywords}

Tomato, Fusarium oxysporum f.sp. lycopersici, Fungicides, Inhibition

\section{Article Info}

Accepted:

08 December 2020 Available Online: 10 January 2021
F.oxysporum is so wide spread, it is a significant problem in many crops. It is economically damaging to the banana industry, and the threat of more virulent strains or mutations to damage previously resistant crops is of major concern. $F$. oxysporum also causes damage to many crops from the family Solanaceae, including potato, tomato, and pepper. Yield losses of effected crops can be high, up to $45 \%$ yield loss of tomato crop has been reported in India. Therefore, present in vitro study was planned and conducted in vitro, in 8 treatments replicated thrice, to assess the efficacy of fungicides against Fusarium oxysporum f.sp. lycopersici, at the Department of Plant Pathology, College of Agriculture, Dhule (MS), during 2018-2020. Results revealed that the fungicides Mancozeb + Carbendazim $(0.125 \%+0.05 \%)$ inhibited 100 per cent growth of pathogen followed by Thiram + Carbendazim $(0.15 \%+0.05 \%)$ which inhibited 93.63 per cent, Carbendazim (0.1\%) inhibited 92.13 per cent, Thiram (0.3\%) inhibited 89.5 per cent, Carboxin $(0.2 \%)$ inhibited 87.25 per cent, Captan $(0.25 \%)$ inhibited 81.13 per cent, Propiconazole $(0.2 \%)$ inhibited 67.50 per cent and Mancozeb $(0.25 \%)$ inhibited 62.25 per cent growth of pathogen $F$. oxysporum f.sp. lycopersici.

\section{Introduction}

Tomato (Lycopersicon esculentum Mill., Solanum lycopersicum L.) from the family solanaceae is one of the most important of the popular vegetables in the world. It is anative of Peru in South America (Rick, 1976). In Europe it absolutely was conjointly reffered as Poma amoris-Amorous apple or love apple. It was also known as Poma peruviana apple of Peru. Only as late as 1880, did the British finally concede that tomato is edible.
It was Robert Gibbon Johanson, an ordinary farmer in the U.S.A who first ate tomato on a hot day of August, 1820 to describe its edibleness. From then onwards, the tomato spread throughout the world. In India, it was introduced from Europe, in the seventeenth century (Kale and Kale, 1984).

India ranks second in the area as well as in production of tomato. The major tomato growing countries are China (30.7\%), India $(11.5 \%)$, USA $(8.1 \%)$, Turkey $(7.0 \%)$ and 
Egypt (5.3\%). In India Andhra pradesh is the leading state in both area and production of tomato which contributes $25.01 \%$ to the total production of tomato in India. $\mathrm{MH}$ ranks 8 th by contributing $4.82 \%$ to the national production (Horticultural Statistics at a Glance 2017). Annual production of tomato in India throughout 2018-19 was 20515.24MT with an area of about 814 thousand ha, and productivity of $27.8 \mathrm{MT} / \mathrm{ha}$ (Anonymous, 2018), In Maharashtra state, it is grown on an area of about 43.64. thousand ha with production of 976.58.MT, and productivity of 22.07MT/ha (Anonymous, 2018).

Many plant diseases heavily depend on agrochemicals and mainly rely on fungicides. These fungicides can prevent infection but not all have curative activity; therefore the interval between sprayings is usually short. In addition to the appearances of more aggressive isolates, and isolates that are no longer inhibited by chemical protectants, hence, the burden on the environment is high. Subsequently, plant pathogens are responsible for large amounts of chemical fungicides applied annually exacerbating control strategies. Various practices are effective in reducing the occurrence of Fusarium oxysporum. Looking to heavy incidence and huge losses incurred by wilt it was thought worthwhile to study the pathogen and Therefore, present study on in vitro efficacy of fungicides against Fusarium oxysporum f.sp. lycopersici, causing tomato wilt was planned and conducted at the Department of Plant Pathology, College of Agriculture, Dhule, during 2018-2020.

\section{Materials and Methods}

Isolation, identification and pathogenicity of Fusarium oxysporum f.sp. lycopersici

Isolation of pathogen associated with wilt of tomato was done by tissue isolation method on PDA. The fungus isolated from diseased specimens and maintained in pure form was tentatively identified on the basis of colony characters and morphological characters and later confirmed from the Department of Plant Pathology, College of Agriculture, Dhule. The pathogenicity of Fusarium oxysporum f.sp. lycopersici was done by soil inoculation technique(sick soil).

\section{In vitro evaluation of fungicides}

Experiment were planned to evaluate in vitro efficacy of different fungicides and conducted with Completely Randomized Design (CRD) and all the treatments replicated thrice against Fusarium oxysporum f.sp. lycopersici, fusarium wilt of tomato by applying Poisoned Food Technique (Nene and Thapliyal, 1993) and using Potato Dextrose Agar as basal culture medium.

The fungal disc of $5 \mathrm{~mm}$ diameter was inoculated at the center of each plate, the plate was incubated in BOD incubator for seven days at temperature of $28^{\circ} \mathrm{C} \pm 2^{\circ} \mathrm{C}$. The plates with potato dextrose agar medium without fungicide were served as control. Observations on colony diameter and sporulation were recorded on seventh day after inoculation as per the following formula given by Vincent (1947).

$\mathrm{I}=\mathrm{C}-\mathrm{T} / \mathrm{C}$ X 100

whereas,

$\mathrm{I}=$ Percent inhibition

$\mathrm{T}=$ Growth $(\mathrm{mm})$ of test the fungus in treated plates

$\mathrm{C}=$ Growth $\quad(\mathrm{mm})$ of the test fungus in untreated control plate

The data obtained was statistically analyzed (Panse and Sukhatme, 1978) and the results were interpreted thereof. 


\section{Results and Discussion}

Invitro efficacy of different fungicides against the Fusarium oxysporum f.sp. lycopersici

Eight fungicides were evaluated in in vitro condition by employing "poisoned food technique". The data obtained on the effect of various fungicides in vitro on the vegetative growth and spore formation of the test fungus Fusarium oxysporum f. sp. lycopersici is presented in Table-1 and Plate-1and graphically dipicted in Fig.1

The results presented Table-1 revealed that the treatment T1 (Mancozeb 63\% + Carbendazim 12\% WP) was significantly superior than rest of all the treatment whereas treatment T2 (Thiram 37.5\% +Carbendazim 50\% WP), T8 (Carbendazim 50\% WP), T7 (Thiram 75\% WP), T3 (Carboxin 75\% WP), T4 (Captan $75 \% \mathrm{WP}$ ), T6 (Propiconazole 25\%EC) and treatment T5 (Mancozeb $75 \% \mathrm{WP}$ ) significantly differ from each other.

Table.1 In vitro effect of fungicides on growth and inhibition of Fusarium oxysporum f.sp. lycopersici.

\begin{tabular}{|c|c|c|c|c|c|}
\hline $\begin{array}{l}\text { Sr. } \\
\text { No. }\end{array}$ & $\begin{array}{l}\text { Fungicides/ } \\
\text { Treatment }\end{array}$ & $\begin{array}{l}\text { Concentratio } \\
\text { n (\%) used }\end{array}$ & $\begin{array}{l}\text { Mean colony } \\
\text { diameter } \\
(\mathbf{m m}) * \text { after7 } \\
\text { days of } \\
\text { inoculation }\end{array}$ & $\begin{array}{c}\begin{array}{c}\text { Sporulati } \\
\text { on }\end{array} \\
\text { on }\end{array}$ & $\begin{array}{l}\text { Percent } \\
\text { inhibition } \\
\text { of } \\
\text { growth** }\end{array}$ \\
\hline 1 & $\begin{array}{l}\text { Mancozeb } 63 \%+ \\
\text { Carbendazim 12\% } \\
\text { WP (T1) }\end{array}$ & $0.125 \%+0.05 \%$ & 0.00 & - & $\begin{array}{c}100.0 \\
(90)\end{array}$ \\
\hline 2 & $\begin{array}{l}\text { Thiram 37.5\% + } \\
\text { Carbendazim 50\% } \\
\text { WP (T2) }\end{array}$ & $0.15 \%+0.05 \%$ & 5.10 & - & $\begin{array}{c}93.63 \\
(75.38)\end{array}$ \\
\hline 3 & $\begin{array}{l}\text { Carboxin } 75 \% \mathrm{WP} \\
\text { (T3) }\end{array}$ & $0.2 \%$ & 10.20 & - & $\begin{array}{c}87.25 \\
(69.07)\end{array}$ \\
\hline 4 & $\begin{array}{c}\text { Captan } 75 \% \text { WP } \\
\text { (T4) }\end{array}$ & $0.25 \%$ & 15.10 & + & $\begin{array}{c}81.13 \\
(64.25)\end{array}$ \\
\hline 5 & $\begin{array}{l}\text { Mancozeb 75\%WP } \\
\text { (T5) }\end{array}$ & $0.25 \%$ & 30.20 & ++ & $\begin{array}{c}62.25 \\
(52.09)\end{array}$ \\
\hline 6 & $\begin{array}{l}\text { Propiconazole } 25 \% \\
\text { EC (T6) }\end{array}$ & $0.2 \%$ & 26.00 & ++ & $\begin{array}{c}67.50 \\
(55.24)\end{array}$ \\
\hline 7 & $\begin{array}{c}\text { Thiram } 75 \% \text { WP } \\
\text { (T7) }\end{array}$ & $0.3 \%$ & 8.40 & ++ & $\begin{array}{c}89.50 \\
(71.09)\end{array}$ \\
\hline 8 & $\begin{array}{l}\text { Carbendazim 50\% } \\
\text { WP (T8) }\end{array}$ & $0.1 \%$ & 6.30 & ++ & $\begin{array}{c}92.13 \\
(73.70)\end{array}$ \\
\hline \multirow[t]{3}{*}{9} & Control (T9) & - & 80.00 & ++ & - \\
\hline & $\mathbf{S E} \pm$ & & 0.07 & & 0.31 \\
\hline & CD at $1 \%$ & & 0.20 & & 0.95 \\
\hline
\end{tabular}

Note:*Average of three replication

** Figuresin parenthesis are square arc sin value

Whereas, Excellent $(++++)$, Good $(+++)$, Medium $(++)$, Poor $(+)$, No sporulation (-) 


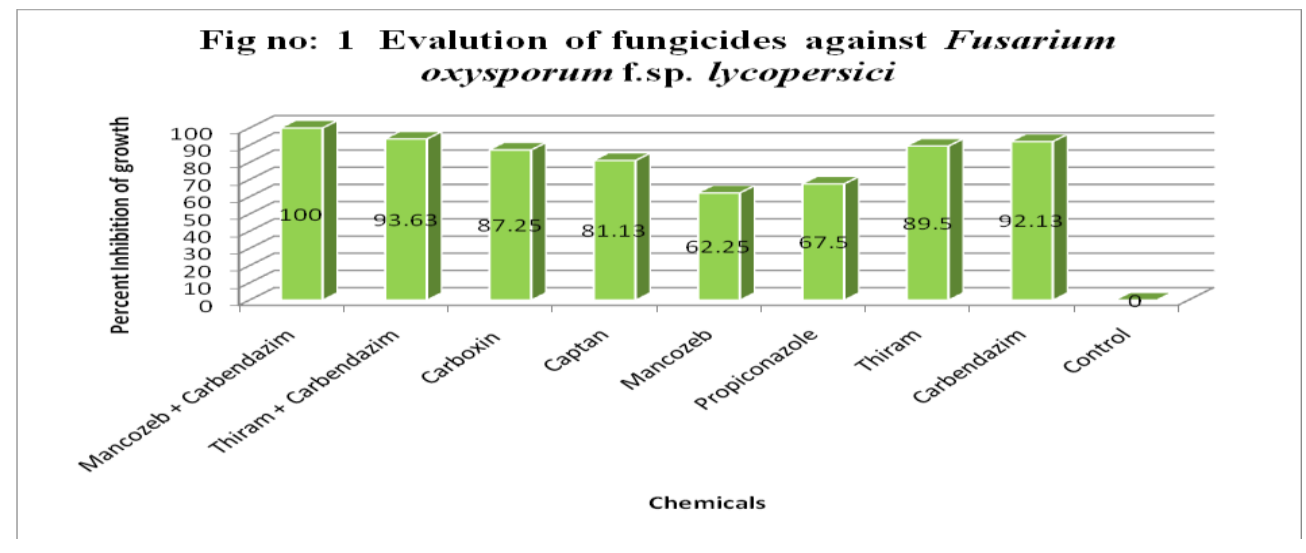

Plate.1 In vitro evaluation of fungicides against Fusarium oxysporum $\mathrm{f}$. sp. lycopersici by poison food technique

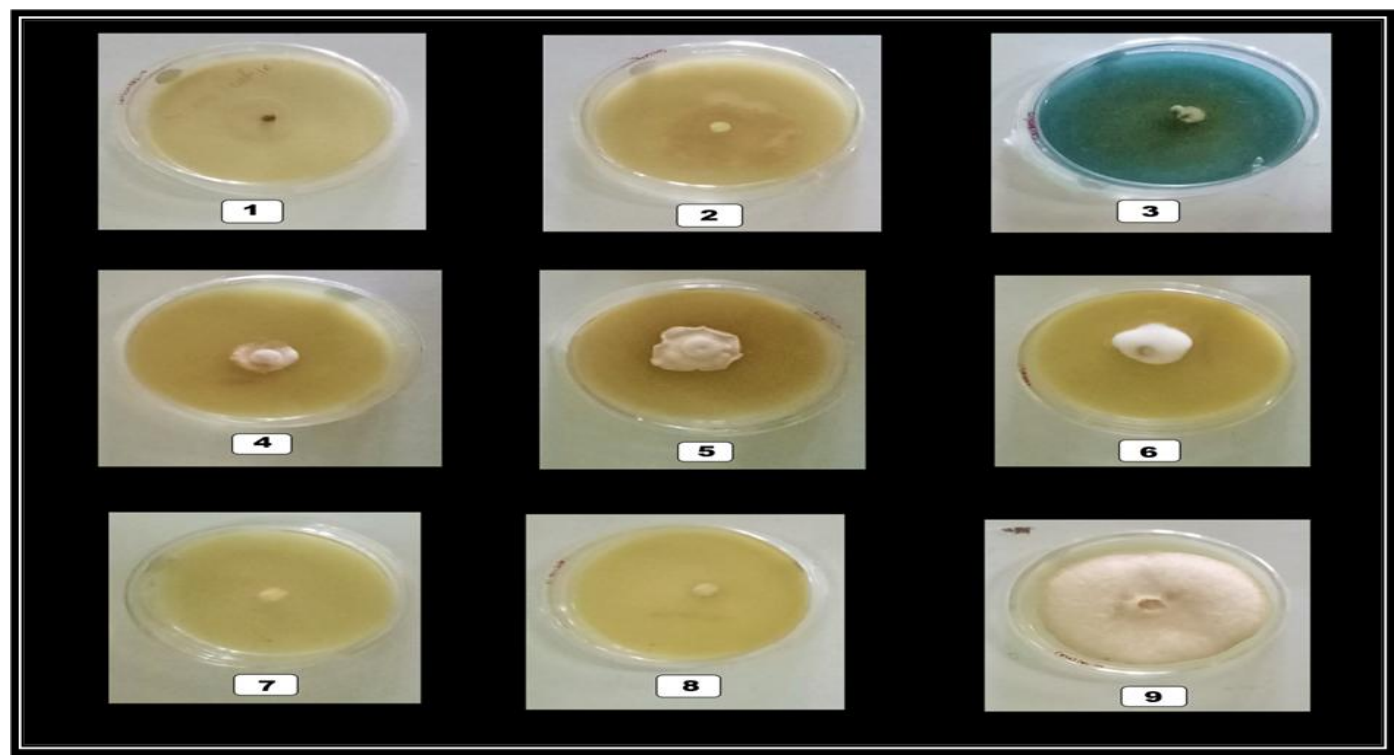

1)Mancozeb + Carbendazim2) Thiram + Carbendazim 3) Carboxin 4) Captan

5) Mancozeb 6) Propiconazole 7) Thiram 8) Carbendazim 9) Control

Fungicide Mancozeb + Carbendazim $(0.125$ $\%+0.05 \%$ ) completely inhibited the growth of the pathogen Fusarium oxysporum f. sp. lycopersicion the potato dextrose agar media. This shows that the fungicide Mancozeb + Carbendazim of the given concentration were 100 per cent effective against to the rest of fungicides regarding inhibiting the growth of pathogen. This was followed by Thiram + Carbendazim $(0.15 \%+0.05 \%)$ inhibited 93.63 per cent growth, then Carbendazim $(0.1 \%)$ inhibited 92.13 per cent growth of pathogen.
However, the fungicides namely Thiram $(0.3 \%)$, Carboxin $(0.2 \%)$, Captan $(0.25 \%)$, Propiconazole $(0.2 \%)$ and Mancozeb $(0.25 \%)$ alone inhibited 89.5 per cent, 87.25 per cent, 81.13 per cent, 67.50 per cent and 62.25 per cent growth of pathogen respectively. This shows that, the fungicide Mancozeb was less effective than Mancozeb + Carbendazim and other fungicides

In the treatment Mancozeb + Carbendazim $(0.125 \%+0.05 \%)$, Thiram + Carbendazim $(0.15 \%+0.05 \%)$, Carboxin $(0.2 \%)$, there was 
no sporulation, while Captan $(0.25 \%)$ had poor sporulation. Propiconazole $(0.2 \%)$, Mancozeb $(0.25 \%)$, Thiram $(0.3 \%)$ and Carbendazim $(0.1 \%)$ had medium sporulation.

From the results it was concluded that, the fungicide Mancozeb + Carbendazim $(0.125 \%$ $+0.05 \%$ ) was proved most effective in inhibiting the growth of Fusarium oxysporum f.sp. lycopersici as compared to other fungicides.

The results are conformity with reports of Quadri et al., (1982), Kalra and Sohi (1984), Etebarian (1992), Poddar (2004), Musmade et al., (2009) and Barhate et al., (2015).

Hence, from ongoing results and discussion, it is concluded that in vitro testing of fungicides against Fusarium oxysporum f.sp. lycopersici revealed that the fungicide Mancozeb + Carbendazim $(0.125 \%+0.05 \%)$, exhibited maximum growth inhibition $(100 \%)$ of the test pathogen and it was found significantly superior over rest of the fungicidal treatments

\section{References}

Anonymous, 2018. National Horticulture Board, Ministry of Agriculture Government of India. Butler, E. J. 1918. Fungi and Disease in plant. pp -251.

Barhate, B. G., Musmade. N. A. and Nikhate, T. A. 2015. Management of Fusarium wilt of tomato by bioagent, fungicides and varietal resistance. Int. $J . \quad P l$ Protect.8(1): 49-52.

Etenbarian, H.R. 1992. Studies of Fusarium wilt of tomato and its chemical control in Varamin area. Iranian J. Agric. Sci. 23:1-14.

Kale, P. N. and Kale, S. P. 1984. Bhajipalautpadan continental publishing, Pune, India. pp. 29.

Kalra, J.S.and Sohi, H.S. 1984. Efficacy of different fungicides against Alternaria tenuisand Fusarium oxysporum under in-vitro conditions. Res. Bull Punjab Agril. Univ. 35:99-102.

Musmade, N., Pillai, T., Singh, K. and Thakur,S.T.2009. Biological and chemical management of tomato wilt caused by Fusarium oxysporumf.sp. lycopersici. J. Soils and Crops. 19(1):118-121.

Nene, Y. L. and Thapliyal, R. N. 1993. Evaluation of fungicides in: Fungicides for Plant Disease Control ( $3^{\text {rd }}$ Ed.). Oxford, IBH Pub. Co., New Delhi: 331. P.P.

Panse, V. G. and Sukhatme, P. V. 1978. Statistical methods for Agricultural Workers. I. C. A. R., New Delhi.

Poddar, R.K., Singh, D. V. and Dubey, S.C. 2004. Management of chickpea wilt through combination of fungicides and bioagents. Indian Phytopath.57(1): 3943.

Quadri, S.M.H., Srivastava, K.J., Bhonde, S.R., Pandey, U.B. and Bhagchandani, P.M. 1982. Fungicidal bioassay against some important pathogen in onions. Pesticides.16(11): 11-16.

Vincent, J. M. 1947. Distortion of fungal hyphae in the presence of certain inhibitors. Nature. 150: 850.

\section{How to cite this article:}

Bhujbal, M. M., C. D. Deokar, D. A. Bachkar, J. S. Suryawanshi and Daingade, N. M. 2021. In vitro Efficacy of Fungicides against Fusarium oxysporum f. sp. lycopersici causing Fusarium Wilt of Tomato. Int.J.Curr.Microbiol.App.Sci. 10(01): 623-627. doi: https://doi.org/10.20546/ijcmas.2021.1001.075 